\title{
Pinna Growth and Development in Relation to Venation in Nephrolepis Species
}

\author{
Aina A. FAJUKE*, A.M. MAKINDE, F.A. OLOYEDE, M.O. ISA
}

Obafemi Awolowo University, Ile-Ife, Osun State, Nigeria; realaina@yahoo.com (*corresponding author)

\begin{abstract}
Growth and development of the pinna in three species $N$. cordifolia, N. exalta(i), N. exalta(ii) and N. furcans were viewed in the department of botany of Obafemi Awolowo University, IIe-Ife campus. The results showed that all the venation of the pinnae of the species consist of a mid-vein and 2 lateral series of dichotomous vein all of which terminate freely near the lamina margins. Because it seems their venation patterns are similar, this might be one of the reasons for grouping them into one genus called Nephrolepis Schott. The development and growth pattern of $N$. cordifolia and $N$. furcans was uniform and consistent, while that of $N$. exalta gave two forms as the young was represented $N$. exalta (i) and the matured as N. exalta (ii). The growth patterns showing variations in the mid-rib, fertile and sterile pinnae provided useful specific distinctions.
\end{abstract}

Keywords: development, growth, Nephrolepis, pinna

\section{Introduction}

Nephrolepis is a genus consisting of about 40 species occurring mainly in the tropics sparingly in the subtropic and only locally extending into the temperate (Friedrich, 2005). Ferns and the so-called ferns allies comprise about 3\% of the vascular plant species. They are ancient non-flowering plants which appeared in the fossil record around 400 million years ago (Kenrick and Crane, 1997). Ferns are group of about 9000-12,000 species of plants classified in the division Pteridophyta when treated as a sub division of tracheophyta (Kartesz, 1994). Most Pteridophytes are basically herbs, some as small as $2-3 \mathrm{~mm}$ and only a minority reach heights of more than $2-4 \mathrm{~m}$.

In ferns, leaf is referred to as frond, new leaves expand by the uncurling or unrolling of a tight spiral crozier or fiddlehead by the method called circinate vernation. Leaf development that is initiated at the tip is called acropetal and this development is characteristics of most modern ferns. Leaves of a few genera have another kind of development. For example Ophioglossum grow by intercalation and are conduplicate rather than circinate. The venation of ferns provides a rich source of information for identification (Wagner, 1979). This could be free, dichotomous or reticulate. In Nephrolepis, Wagner (1977) reported that fertile leaves are called sporophyll, the sterile leaves are trophophylls. The leaf on the basis of spore is divided into three; trophophyll which does not produce spore; sporophyll which produces few spores and brophophyll which produces large amount of spores. The leaflets or pinnae of Nephrolepis are simple, sessile, and small in size and possess a single median vein that fails to reach the apex. Such leaves are called microphyllous or microphylls (Pray, 1970). These leaves are hairy with serrated margins. The leaf base is decrrent in Lycopodium complanatum and lacks a ligule. Leaf base in Nephrolepis could be cordate in $N$. furcans or truncate in $N$. exaltata. The leaves are spirally arranged and densely cover the branches as a whorled in Lycopodium species (Bhambie, 1965).

With the exception of certain grapeferns (Botrychium) and Isoetes, no modern pteridophyte displays true secondary growth: the tissues are all primary, derived from a terminal meristem. Pteridophytes have no cambium and they lack cork and secondary vascular tissues. The stem of pteridophytes are mainly true rhizome, i.e stems that run horizontally at or just beneath the surface of the ground. The growing tips however may be ascending or erect. Some ferns have upright stems like tiny tree trunks (caudices) and are unable to form colonies except for occasional upright branching, as in Botrychium (Wagner, 1979). Although most ferns are capable of propagating by rhizomes others spread from leaves or root. Anatomically the stem of pteridophytes are simpler than in most plants because they are made up only primary tissues which is common in the leptosporangiate ferns of which Nephrolepis belong.

In common ferns like Adiantum, Pteris and Dryopteris the leaf or leaflet can bear sori on the abaxial surface but the genus Osmunda have special pinnae set aside for bearing 
sporangia that are the bodies in which spores are produced. It is important, especially in ferns, to obtain fertile leaves that bear sporangia because this usually greatly simplifies identification especially at the generic level.

The aim of this study is to determine the patterns of variation in the growth and development in relation to venation and their value in species identification and classification.

\section{Materials and Methods}

Some mature fronds were collected from the fern garden of the Department of Botany, Obafemi Awolowo University, Ile-Ife. The plants were identified using IFE herbarium specimens at the Department of Botany, Obafemi Awolowo University, Ile-Ife, Nigeria and fern floras (Alston, 1959; Agnew, 1974).

\section{Venation patterns}

Some sizeable portion of fresh mature leaflets of each species was taken from the standard median levels (i.e midway between the apex and the base), washed and decolorized by boiling in $70 \%$ ethanol for ten minutes using hot plate, to remove chlorophyll. The partially decolorized leaflets were washed carefully with 3-5 changes of distilled water to remove all the traces of alcohol. The leaflets were cleared by boiling in sodium hydroxide solution for five minutes. The cleared leaflets were soaked in Petri dish containing domestic bleach (JIK) for few seconds under the sun (to hasten the bleaching process). The leaflets were washed with distilled water and then stored in ethanol. The leaflets were stained in Alcian blue and counter stained with Toludine blue (to enhance constrast) and then mounted on a clean slide with $25 \%$ glycerol. Both abaxial and adaxial surfaces of the leaflets were used to study venation patterns. Photomicrographs were taken for the abaxial and adaxial surfaces of the leaflets to show the venation patterns.

\section{Staining}

The sections were stained in Safranin O for three minutes, rinsed in water thrice and counter stained in Alcian blue for three minutes and rinsed in water thrice. Stained sections were treated in series of grades of ethanol $(50 \%, 70 \%, 80 \%, 90 \%$ and $100 \%)$ for dehydration and differentiation processes. Dehydrated and differentiated sections were treated in absolute xylene to remove traces of ethanol, to clear (making it more transparent) and to provide medium that is mixable with DPX mountant around the sections. The sections were mounted on clean slides in DPX mountant and were properly labelled.

\section{Examination of slides}

Microscopic observations were done using 3013 ACCU Trinocular microscope with Digital camera mounted on the microscope. Tissues, cells and cell inclusions were identified, described and recorded for taxonomic studies.

\section{Results}

Venation pattern of the leaflet of $N$. cordifolia (Fig. 1a, $b$ and c)

The venation pattern is open dichotomous and parallel having 28-35 lateral veins. Primary vein is divided into veinlets and did not reach the apex of the leaflet. The secondary veins
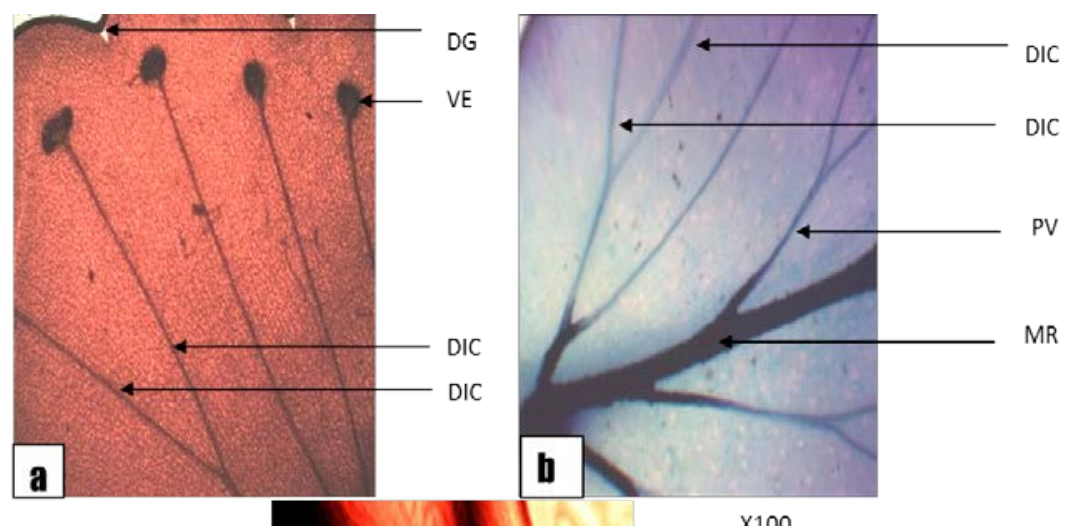

$\mathrm{X} 100$

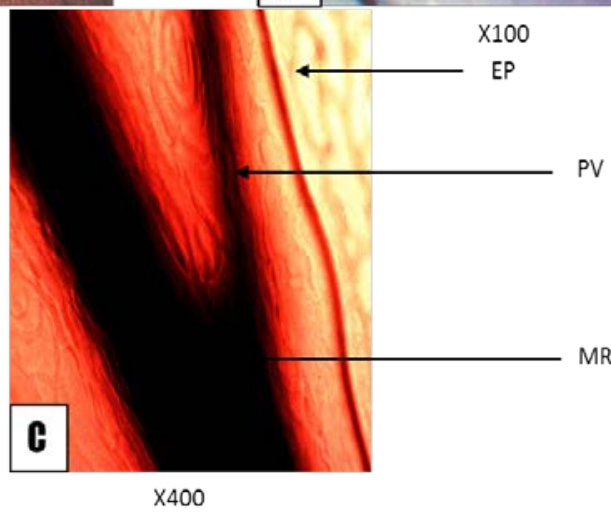

Fig. 1. Venation pattern of the leaflet of $N$. cordifolia

DIC- dichotomously branched vein; MR- mid-rib; PV- primary vein; SV- secondary vein;TR- trichome; VE- vein ending in hydathode/sori;VI- vein; VT- veinlet; EPepidermal cell; DG- deep groove at the margin;ST- stomata 
298
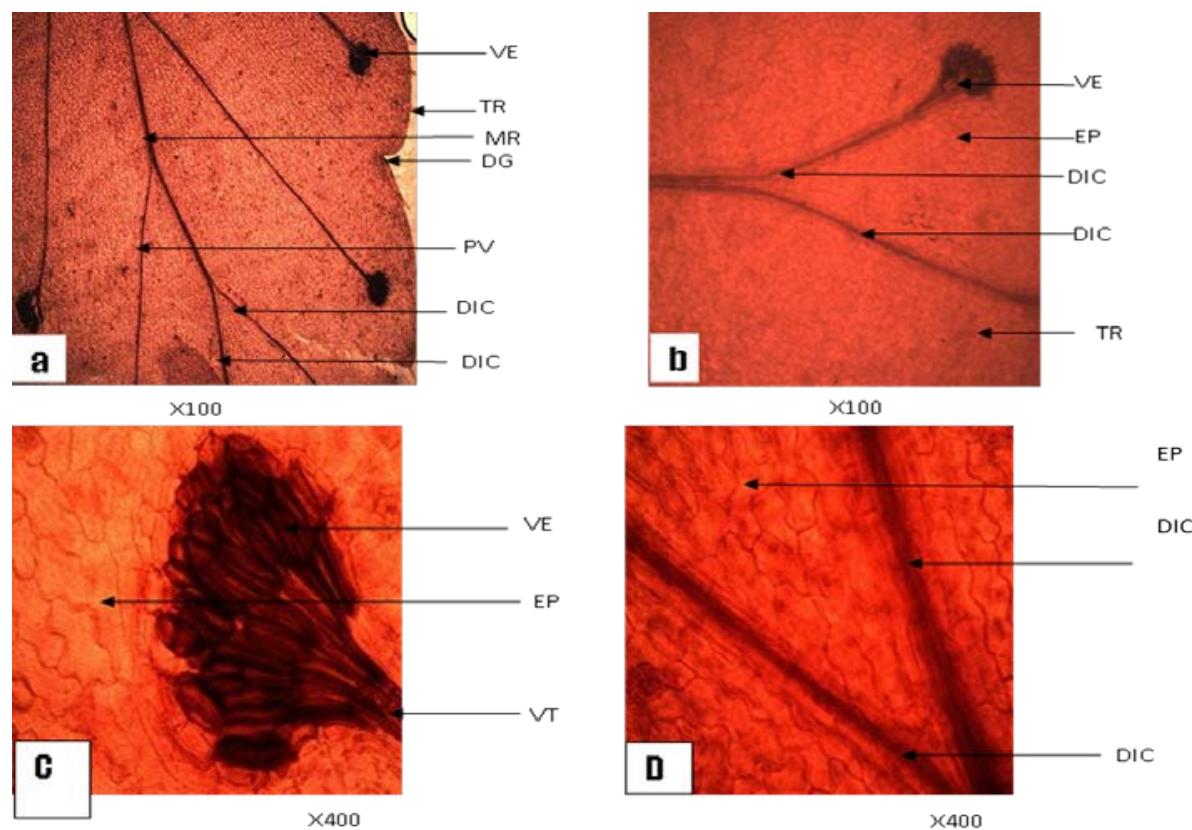

Fig. 2. Venation pattern of the leaflet of N. exalta (i)

DIC- dichotomously branched vein; MR- mid-rib; PV- primary vein; SV- secondary vein;TR- trichome; VE- vein ending in hydathode/sori;VI- vein; VT- veinlet; EPepidermal cell; DG- deep groove at the margin;ST- stomata

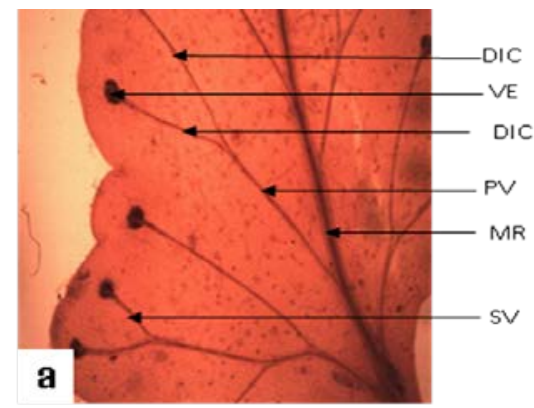

$\times 100$

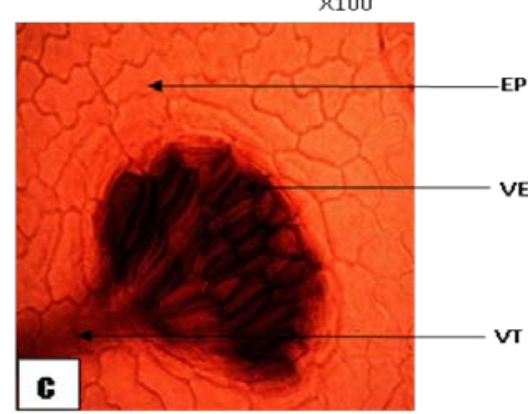

$\times 400$
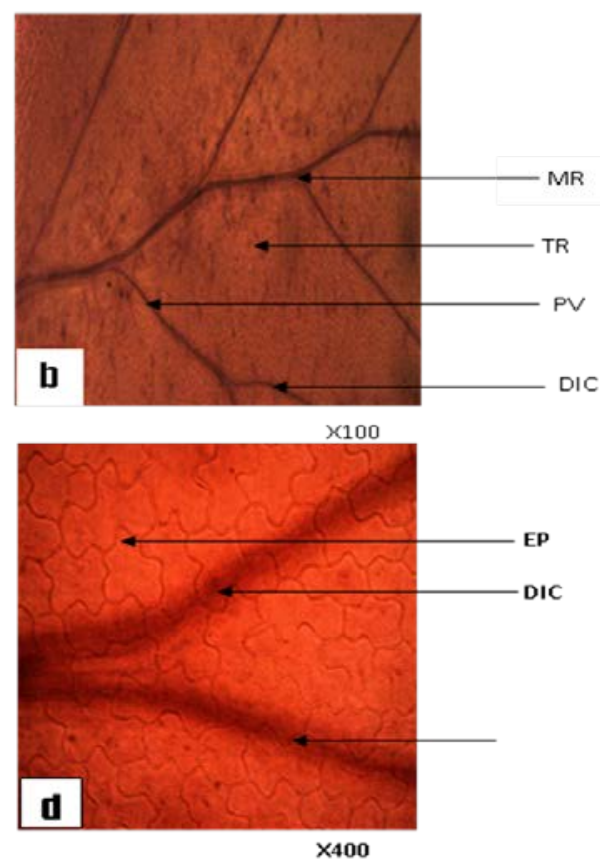

Fig. 3. Venation pattern of the leaflet of N. exalta (ii)

DIC- dichotomously branched vein; MR- mid-rib; PV- primary vein; SV- secondary vein;TR- trichome; VE- vein ending in hydathode/sori;VI- vein; VT- veinlet; EPepidermal cell; DG- deep groove at the margin;ST- stomata

diverged, parallel but did not reach the leaflet margin. Veins are glabrous.Veinlet ending terminate with sori which are oblong. No areoles and costae were neither sheathed with parenchyma cells nor hairy but few starch grains were seen. There is depression or groove at the margin.

Venation pattern of the leaflet of $N$. exalta (i) (Fig. 2a, b,c and d)

Venation pattern in the unipinnate $N$. exalta leaflet is parallel, open dichotomously branched. Veinlets terminating with oval-shaped hydathode. Veins were between 8-12 per field. The secondary veins diverged, parallel and did not reach the margin. Costae are neither sheathed with parenchyma cells nor hairy. Veins were glabrous. No areoles though starch grains are present. There is depression or groove at the margin.

Venation pattern of the leaflet of $N$. exalta (ii) (Fig. 3a, b,c and d)

The venation pattern of $N$. exalta bipinnate was open, parallel and dichotomously branched. Veins were glabrous. The 

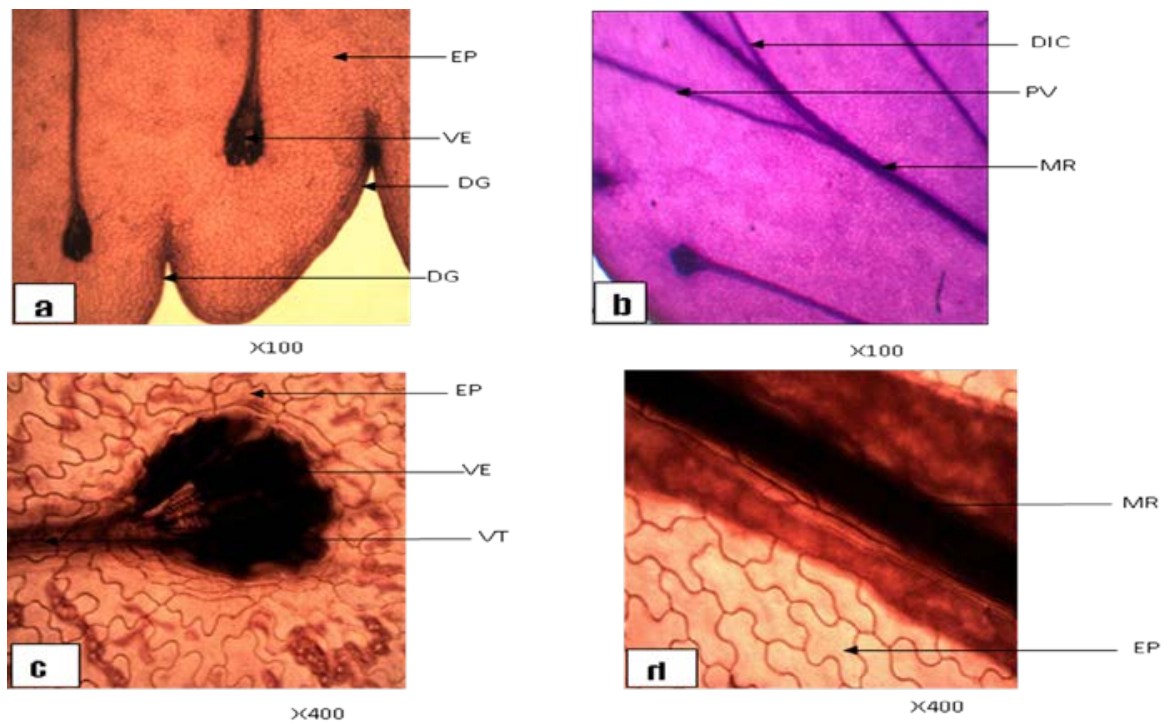

Fig. 4. Venation pattern of the leaflet of $N$. furcans

DIC- dichotomously branched vein; MR- mid-rib; PV- primary vein; SV- secondary vein;TR- trichome; VE- vein ending in hydathode/sori;VI- vein; VTveinlet; EP- epidermal cell; DG- deep groove at the margin;ST- stomata

secondary veins diverged, parallel but did not reach the margin. The veinlets do not reach the margin and terminate with oval-shaped hydathode. No areole seen. The costa is divided into veinlets before it reaches the apex. Costae neither sheath with parenchyma cells nor hairy. There is depression or groove at the margin. Numerous starch grains were seen on the leaflet.

Venation pattern of the leaflet of $N$. furcans (Fig. $4 a, b, c$ and d)

The venation pattern was open, reticulate and dichotomous. Lateral veins were 40-42 per field. Veins were glabrous. The primary vein did not reach the apex of the leaflet. There were no trichomes on the leaflets surface. No areoles. Costae neither sheath with parenchyma cells nor hairy. Veinlets terminated with oval-shaped hydathode. Numerous starch grains were seen. There is depression or groove at the margin.

Note: $N$. exalta is the only species that has two forms of leaf type unipinnate at young stage and bipinnate at maturity stage.

\section{Discussion}

\section{Anatomical studies of the leaflets}

Venation that was said to be a neglected character has been used by Levin (1986) to provide insight into relationship within subfamily Phyllanthoideae. Venation pattern is useful in delimiting the species of Nephrolepis genus and according to Pray (1970) the venation of the pinna of Nephrolepis consists of a mid-vein and two lateral series of dichotomous veins all of which terminate freely near the margin. Pray further recorded that without exception all branches of the venation system have vein tips markedly dilated into hydathode at the abaxial surface of the pinna. But it seems their venation patterns are similar and this might be one of the reasons for grouping them into one genus called Nephrolepis Schott. The bewildering variety of leaf form or arrangement provides many of the most useful characters of pteridophyte taxonomy. The spore-producing organs are borne on the leaves and those that do so are called fertile and those without, sterile. In this study, venation pattern can be grouped into two according to the veinlet ending as the fertile pinnae in $N$. cordifolia terminated at the adaxial surface with the reproductive structure sori (Fig. 1a) while the veins in the sterile leaflets ( $N$. exalta (i), $N$. exalta (ii), $N$. exaltata and $N$. furcans) (Figs. 2a, 3a and $4 \mathrm{a}$ ) do not terminate with sori. The reproductive sori can be reasonably employed in delimiting the Nephrolepis species. In all the three species, the vein arrangement is dichotomously branched, free but the mid-rib is different across the genus. The thickness of the mid-rib of the members of the genus can be used in the classification and separation of taxa. $N$. cordifolia had the highest with $5 \mu \mathrm{m}$ both at the abaxial and adaxial surfaces while $N$. exalta(ii) recorded the least $4 \mu \mathrm{m}$ (abaxial) and $3 \mu \mathrm{m}$ (adaxial).

Quantitative attributes of venation pattern reveal a general significant difference among the species. N. cordifolia, and $N$. furcans had significantly high values for the distance between leaflet margin and veinlet endings than $N$. exalta.

\section{Conclusions}

The results from venation studies brought to the fore the affinities, similarities and differences among members of the genus Nephrolepis studied. All the three species vein arrangement was dichotomously branched but the veinlet ending can be grouped into two; the fertile leaflets of $N$. cordifolia has its veinlets terminated at sori, while the sterile leaflets of $N$. exalta(i), $N$. exalta(ii) and $N$. furcans do not have sori. The presence or absence of spores can be used for delimitation of species. The following artificial key based on these observations allows separation of all taxa:
la Spores present
$1 b$ Spores absent
2a Parallel veins.................... exalta
2b Articulate veins............N. furcans
3a Unipinnate pinna..........N. exalta(i)
3b Bipinnate pinna............. exalta(ii) 
300

\section{References}

Adedeji O (2004). Leaf epidermal studies of the species Emilia Cass. (Senecioneae, Asteraceae) in Nigeria. Botanical Lithuanica 10(2):121-133.

Agnew $\mathrm{AD}$ (1974). A flora of the ferns and herbaceous flowering plants of Kenya. Oxford University Press, London pp 1-65.

Alston AHG (1959). Ferns and ferns-allies of West Tropical Africa 2nd Ed. Crown Agents for Oversea Governments and Administrations, London pp 1-60.

Bhambi S (1965). Proceeding Indian Academy of Science 58:153-164.

Bower FO (1963). The Ferns. The leptosporangiate ferns. Today and tomorrow's book agency, Vol 111. New Delhi, India.

Camus JM, Jermy AC, Thomas BA (1991). A world of Ferns. 2nd Ed. Natural History Museum Publications. Cromwell Road, London pp 6-157.

Friedrich L (2005). Nephropidaceae. www.Flohmueller.de. Accesed August, 2008.

Illoh HC (1995). Foliar epidermis and petiole anatomy of four species of Celosia L. in Nigeria. Feddes Repertorium 106(1-2):15-23.

Kartesz JT (1994). A synonymized checklist of the vascular flora of the United States, Canada and Greenland. Timber Press. A product of the Biota of North America program. Botany 620 Home page. Accessed December, 2000.
Kenrick P, Crane R (1997). The origin and early evolution of plants on land. Nature 389(4):33-39.

Levin GA (1986). Systematic foliar morphology of Phyllanthoideae (Euphorbiaceae) I. Conspectus. Annals of the Missouri Botanical Garden 73:86-98.

Ogundipe OT (2004). Foliar micromorphology of the species of Blighia konig (Sapindaceae) in West Africa. Nigerian Journal of Botany 17:53-61.

Oloyede FA, Akomolafe FG, Oladipo OT (2011). Comparative folia anatomical and morphological studies of Nephrolepis biserrata (Swartz) Scott and N. undulata (Swartz). SM. in Nigeria. Journal of Science and Technology 31(2):1-10.

Pray T (1970). Ontogeny of the open dichotomous venation in the pinna of the fern Nephrolepis. American Journal of Botany $47(5): 319-328$.

Scatena VL, Giuletti AM, Borba EL, van der Berge C (2005). Anatomy of the Brasilian Ericolaceae in correlation with taxonomy and habitat using multivariate analysis. Plant Systematics and Evolution 253(1):1-22.

Wagner FS (1977). Pteridophytes of North America Flora, Vol 1. Chp. 10.

Wagner FS (1979). Pteridophytes of North America Flora, Vol 1 Chp. 12. 